\title{
EVALUATION OF IN VITRO ACTIVATION OF BOVINE ENDOMETRIAL AND VAGINAL EPITHELIAL AND BLOOD MONONUCLEAR CELLS TO PRODUCE NITRIC OXIDE IN RESPONSE TO MYCOPLASMA BOVIS, MYCOPLASMA BOVIGENITALIUM AND UREAPLASMA DIVERSUM
}

\author{
Regiani Nascimento Gagno PÔRTO ${ }^{1}$, Ana Paula JUNQUEIRA-KIPNIS², \\ Marco Antonio de Oliveira VIU ${ }^{3}$, Rafaela Cavalcanti TEIXEIRA ${ }^{1}$, \\ Maria Lucia GAMBARINI* ${ }^{1 *}$
}

\begin{abstract}
${ }^{1}$ Veterinary and Animal Science School, Federal University of Goias, Campus II, Av Esperança sn, Campus Samambaia, ZIP Code 74.690.900, Goiania,Goiás, Brazil; ${ }^{2}$ Immunology Laboratory, Institute for Tropical Pathology and Public Health Federal University of Goiás, R.225, s/n ZIP code 74605-050, Goiania, Goias, Brazil; ${ }^{3}$ Veterinary School, Federal University of Jataí, R. Riachuelo, 1530, ZIP Code 74804-020, Jataí, Goias, Brazil
\end{abstract}

(Received 23 January 2020, Accepted 23 March 2021)

Genital mycoplasmosis is a condition present in bovine production systems, and the most important agents involved are Mycoplasma bovis, Mycoplasma bovigenitalium and Ureaplasma diversum. Some aspects of their pathogenesis remain unclear. This study was designed in order to evaluate their ability to stimulate mononuclear cells from the endometrium, vagina and peripheral blood of cycling and healthy cows to produce nitric oxide (NO). Cellular cultures of endometrial, vaginal and peripheral blood cells from 33 healthy cows were cultivated with Mycoplasma bovis, Mycoplasma bovigenitalium and Ureaplasma diversum originated from the $4^{\text {th }}$ passage in culture broth and the NO production was measured by the Greiss reaction. Confirmation of the presence of mononuclear cells and of the agents during and after the NO assay was done by Giemsa stained smears and further cultivation and detection by PCR reaction. Mononuclear cells from all samples produced NO. Mycoplasma bovigenitalium stimulated higher NO production than the others $(\mathrm{p}<0.05)$. Endometrial cells produced less $\mathrm{NO}$ than vaginal or blood cultured cells. In conclusion, it seems that Mycoplasma bovis, Mycoplasma bovigenitalium, and Ureaplasma diversum are able to activate mononuclear cells and induce the production of $\mathrm{NO}$, thus suggesting that this pathway is elicited in response to the primary infection by these agents. More studies are necessary to verify why these agents remain in the bovine reproductive tract for long periods and how they reassume deleterious effects.

Key words: cow, Genital micoplasmosis, innate immunity, infection

\footnotetext{
*Corresponding author: e-mail: mlgambarini@pq.cnpq.br
} 


\section{INTRODUCTION}

Mycoplasmas and ureaplasmas are opportunistic pathogens for humans and animals, considered as causal agents of Granular Vulvovaginitis Syndrome in bovines [1]. They belong to the Mollicutes class, and infection by mycoplasmas and ureaplasmas is connected with injuries in many organs. The economic losses caused by them is unquestionable. The occurrence of Mycoplasma bovis, Mycoplasma bovigenitalium and Ureaplasma diversum is linked to infertility and increased numbers of services per conception, early embryo death, and losses during the perinatal period [2].

Because of their capacity to colonize mucosal surfaces of the nose, eye, middle ear, vagina, and mammary gland [3] the dissemination between animals can occur via aerosolization of nasal secretions [4] or ingestion of contaminated colostrum or milk [5]. Of the risk factors related to their occurrence in dairy cattle the concomitant infection (Mycolasma spp and Ureaplasma diversum) presented the highest odds ratio (OR, 5.67, $\mathrm{P}<0.00010$ [6]. Histopathological changes in the uterus and vagina of heifers during natural infections are characterized by mononuclear cell infiltrations, suggesting cellular response and stimulation of inflammatory mediators [7]. Due to the limited available information regarding the pathogenesis of these organisms, little is known about how the bovine immune system responds to this infection. Despite the fact that these organisms do not have a rigid cell wall, they have a large number of lipoproteins associated with the membrane lipids called LAMPs [8]. Due to the limited capacity of biosynthesis, most of the mycoplasmas have a specific form of parasitism in the host and its tissues, and developed mechanisms that allow the interaction with the host's immune response and colonization of other hosts, and an efficient mechanism of adhesion is requirement for their survival and pathogenicity, avoiding elimination through mucous secretions [9].

Nitric oxide (NO) is a physiological signaling molecule synthesized by NO synthase. It mediates various cell functions, including the cytotoxic and cytostatic effects of the immune system against microorganisms and tumor cells. The cytotoxicity of $\mathrm{NO}$ results from direct action or reaction with other compounds released during the inflammatory process. NO is known as a physiological regulator of the reproductive tract of mammals, involved in tissue remodeling and is present in the endometrium, cervical and vaginal mucosa [10]. NO was associated with the occurrence of subclinical and clinical endometritis [11,12].

Based on the evidence that NO is associated with the function of mononuclear cells, and that mycoplasmas and ureaplasmas are able to colonize the bovine reproductive tract to promote severe local reactions, without, however, exercise intracellular parasitism, but are very efficient to evade the host's immune defense systems [13] , we hypothesize that Mycoplasma bovis, Mycoplasma bovigenitalium and Ureaplasma diversum would be able to activate bovine mononuclear cells in vitro and thus trigger a response signal of recognition in the reproductive tract. This study was carried out to evaluate the in vitro ability of these microorganisms to activate mononuclear cells from the 
endometrium, vaginal mucosa and peripheral blood of cows by a NO production assay and so to contribute to the understanding of their pathogenesis.

\section{MATERIAL AND METHODS}

This study was conducted according the Brazilian guideline for the care and use of animals in education and scientific research activities (DBCA) and was approved by the Ethics Committee for the use of animals of the Federal University of Goias, Brazil (\#PI04150-2019).

\section{Reagents}

All reagents and material used were prepared in the laboratories of Animal Reproduction and Immunology of the Federal University of Goias, Brazil, except those noted in the text.

\section{Animals - biological samples}

Endometrial, vaginal and venous blood were obtained from 33 healthy, not pregnant and presenting normal estrus cycling cows, without vulvovaginal lesions and negative for Mycoplasma spp, Ureaplasma diversum and BHV-1, belonging to the herd of the Veterinary and Animal Science School. To prevent the effect of the estrus cycle phase on the results, all animals were previously treated with $2 \mathrm{~mL}$ of estradiol valerate $24 \mathrm{~h}$ before the procedures. Sterile disposable cytobrushes were used to collect endometrial and vaginal cells. A procedure similar to artificial insemination was performed to access the endometrium. The cytobrush was connected to a sterile infusion pipette and inserted into a stainless steel sheath, covered with a plastic sheath, and introduced through the cervix, the plastic sleeve was perforated thus allowing the stainless steel sheath to rich the uterus. The cytobrush was pushed out of the sheath and gently rubbed on the endometrium, then pulled back into the sheath, and removed from the uterus. The cytobrush was removed from the sheath and transferred to a sterile plastic tube containing $4 \mathrm{~mL}$ of buffered phosphate saline (PBS). Vaginal samples were obtained using a sterile cytobrush rubbed directly on the cleared mucosa of the vagina, and transferred to another plastic tube with PBS. Blood samples were obtained by coccygeal venipuncture into heparinized tubes. All samples were transported on ice to the laboratory.

\section{Cell cultures}

Once in the laboratory, the tubes containing the cytobrushes were shaken to remove endometrial and vaginal cells. The cells were washed in PBS with added antibiotics and counted in a Neubauer chamber. After resuspension in RPMI 1640 medium (GibcoInvitrogen Corporation, NY, USA) supplemented with 15\% fetal calf serum and antibiotics the cells were cultivated in an incubator $\left(37^{\circ} \mathrm{C}, 5 \% \mathrm{CO}_{2}, 95 \%\right.$ air) for $48 \mathrm{~h}$ 
in sterile polystyrene culture plates (Corning Incorporated Costar, NY, USA) with 96 wells and capacity for $50 \mathrm{~mL}$, at density of 2 X $10^{6}$ cell $/ 100 \mu \mathrm{L}$.

Blood mononuclear cells were isolated by density gradient centrifugation, in the FicollPaque (SIGMA, St. Louis, Missouri, USA) interface. Anticoagulant-treated and diluted blood was layered on the Ficoll-Paque solution and centrifuged. During centrifugation, lower density lymphocytes and monocytes were retained between the plasma and the Ficoll-Paque solution. Cells were washed three times $\left(1400 \mathrm{rpm}, 4^{\circ} \mathrm{C}\right.$, for $\left.5 \mathrm{~min}\right)$ in PBS containing antibiotics, and the sediment was re-suspended and cultivated in the same way as the endometrial and vaginal cells, in RPMI 1640 medium plus 15\% fetal calf serum and antibiotics.

\section{Mycoplasmas and Ureaplasma cultures}

Fresh cultures obtained of the $4^{\text {th }}$ in vitro passage of Mycoplasma bovis (ATCC strain 25523, Donetta) and Mycoplasma bovigenitalium (ATCC strain 49783) and Ureaplasma diversum (ATCC strain 49783) were used. Mycoplasmas were cultured in Hayflick's broth and ureaplasmas in broth $\mathrm{U}_{\mathrm{b}}$, according previous reports [2]. Cultivations were carried out for 18-24 h. For the ureaplasma culture the color change is from yellow to pink. The final concentrations of mycoplasmas and ureaplasma, measured by counting

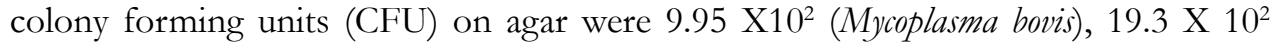
(Mycoplasma bovigenitalium) and $2.0 \times 10^{4}$ (Ureaplama diversum).

\section{Cell stimulation and NO assay}

Stimulations were carried out in 96-well plates. Mononuclear cells were stimulated with $20 \mu \mathrm{l}$ of the fresh culture broth and incubated during $48 \mathrm{~h}\left(37^{\circ} \mathrm{C}, 5 \% \mathrm{CO}_{2}, 95 \%\right.$ air). After the incubation time, $50 \mu \mathrm{l}$ of the supernatants were transferred to another plate, and incubated with $50 \mu$ l of Griess reagent at room temperature for $10 \mathrm{~min}$. The absorbance at $540 \mathrm{~nm}$ was measured in the microplate reader. The accumulation of $\mathrm{NO}_{2}$, a stable end product of $\mathrm{NO}$ formation, in conditioned media was measured as an indicator of $\mathrm{NO}$ production. $\mathrm{NO}_{2}^{-}$in the samples was calculated from a standard curve of sodium nitrite. Supernatants of not stimulated mononuclear cell cultures were used as the control. Results were expressed in nM. All the assays were performed in duplicate.

Immediately after withdrawal of the supernatants two aliquots of the sediment in the plate were taken (stimulated and non-stimulated). The first were used to determine the presence and concentration of Mycoplasma bovis, Mycoplasma bovigenitalium and Ureaplasma diversum. After an $18 \mathrm{~h}$ period of incubation under aerobiosis condition $\left(37^{\circ} \mathrm{C}\right) 0,3 \mathrm{~mL}$ of Hayflick and Ub broths were transferred to agar Hayflick and Ub, cultivated at $37^{\circ} \mathrm{C}$ under microaerophilia during $48-72 \mathrm{~h}$.

Smears were produced from the second aliquots, stained with Giemsa, and analyzed by optical microscopy (400X) to verify the presence of epithelial and mononuclear cells, 
as well as the presence of microorganisms. Samples of supernatants and sediments were processed according routine microbiological methods to assure that no other microorganism was present.

\section{Statistical analysis}

Data were analyzed using the WINSTAT software [14]. Differences were tested using Kruskal-Wallis. Statistical significance was set at $P<0.05$.

\section{RESULTS}

Cellular cultures of all samples resulted in a satisfactory number of mononuclear cells to conduct the $\mathrm{NO}$ assay $\left(2 \times 10^{6}\right.$ cells $\left./ 100 \mathrm{~mL}\right)$, but epithelial cells were present in endometrial and vaginal samples. None of the samples showed growth of other microorganism. Regarding the tested Micoplasmataceae, mycoplasmas and ureaplasma were capable of stimulating the NO production from mononuclear cells.

There were differences between in vitro NO production of blood cell culture, vagina and uterus (Table 1). NO production was verified in all cultures (exposed or not), but regardless to the agents, higher NO production was present in cell cultures exposed to Mycoplasma bovigenitalium when compared to Mycoplasma bovis and Ureaplasma diversum.

Table 1. NO production measured as nitrate $(\mathrm{nM} / \mathrm{mL})$ secreted by mononuclear cells from peripheral blood, vagina and endometrium of cows, stimulated or not with a fixed dose of Mycoplasma bovis, Mycoplasma bovigenitalium and Ureaplasma diversum

\begin{tabular}{lcccc}
\hline \multicolumn{5}{c}{$\mathbf{M} \pm$ SEM } \\
\hline Cell culture & $\begin{array}{c}\text { Medium } \\
\mathbf{5 0} \boldsymbol{\mu L})\end{array}$ & $\begin{array}{c}\text { Mycoplasma } \\
\text { bovis }\end{array}$ & $\begin{array}{c}\text { Mycoplasma } \\
\text { bovigenitalium }\end{array}$ & $\begin{array}{c}\text { Ureaplasma } \\
\text { diversum }\end{array}$ \\
\hline Blood & $3.0 \pm 0.4^{\mathrm{a}}$ & $4.2 \pm 0.3^{\mathrm{aB}}$ & $4.6 \pm 0.3^{\mathrm{bB}}$ & $4.4 \pm 0.2^{\mathrm{bB}}$ \\
\hline Vagina & $3.1 \pm 0.4^{\mathrm{A}}$ & $3.8 \pm 0.5$ & $4.2 \pm 0.6^{\mathrm{B}}$ & $3.9 \pm 0.4^{\mathrm{B}}$ \\
Endometrium & $2.5 \pm 0.4^{\mathrm{aA}}$ & $2.9 \pm 0.5^{\mathrm{aA}}$ & $4.8 \pm 0.8^{\mathrm{bB}}$ & $2.5 \pm 0.5^{\mathrm{aA}}$ \\
\hline
\end{tabular}

Distinct low-case letters in the lines indicate differences $(\mathrm{P}<0.05)$

Distinct capital letters in the columns indicate differences $(\mathrm{P}<0.05)$

The evaluation of Giemsa stained smears showed the presence of microorganisms, mononuclear and epithelial cells. The microorganisms were recognized as structures with spherical shape and thin filaments. Bacteria grew satisfactory after the NO assay. The numbers of colony forming units (CFU) of Mycoplasma bovis and Mycoplasma bovigenitalium were $8.4 \times 10^{3} \mathrm{CFU} / \mathrm{ml}$ and $10.04 \times 10^{3} \mathrm{CFU} / \mathrm{mL}$, respectively, and for Ureaplasma diversum the number of CFU and color change units (CCU) were $1.04 \times 10^{3}$ $\mathrm{CFU} / \mathrm{mL}$ and $10^{4} \mathrm{CCU} / \mathrm{mL}$. 


\section{DISCUSSION}

Macrophages release NO by a variety of stimuli, such as bacterial products and cytokines, and some mycoplasmas are able to induce this reaction. The NO production apparently allows the macrophages to sustain cytostatic and cytotoxic activity against bacteria, viruses, protozoa, helminths, and at the same time, enables the macrophages to produce other substances to destroy other agents [15]. It was suggested that only the bovine macrophages, but not the monocytes, are able to express high levels of iNOS by exposure to bacterial constituents [16], which would explain the lower concentrations of NO found in peripheral blood samples.

Although the iNOS can be expressed by uterine leukocytes (macrophages and lymphocytes) in response to inflammatory cytokines [10], in the present study adherent cells were cultured during $48 \mathrm{~h}$ before the NO assay, time not enough to allow the maturation into macrophages. The activation of bovine monocytes and macrophages to produce NO is dependent on iNOS, and it was shown, in vitro, that monocytes acquire the ability to respond to bacterial stimuli through the synthesis of $\mathrm{NO}$ during the differentiation to macrophages [16].

NO production is an action originated in the cells of the immune system [15]. In this study there was a wide variation in the production of $\mathrm{NO}$, measured as nitrate, which was higher by the vaginal cells. This may be related to the amount of obtained cells, and we can speculate about how fast the response of mononuclear cells present in the vaginal mucous must be, since this is the first barrier to contain the microorganisms during the infection process.

Mycoplasma bovis is considered the most pathogenic bovine mycoplasmas and is involved in many disorders [3]. Present results show a lower response of cellular culture to the stimuli of $M$. bovis, when compared to $M$. Bovigenitalium, suggesting a deficiency of mononuclear cells to recognize M. bovis. On the other hand, Mycoplasma bovigenitalium is common in semen, prepuce, vestibule and vagina of cattle, although few animals of the same herd show clinical manifestations associated to this mycoplasma $[17,18]$. According to the data in Table 1, all cellular cultures exposed to Mycoplasma bovigenitalium showed results regarding NO production as an effect of the stimulation, with differences from the other agents. Infections with $M$. bovigenitalium have been reported to be self-limiting, with a tendency to recovery over a period of few weeks or months. In bulls the infection was verified in the vesicular gland, persisting for over a year, and inducing a local immune response. Present results suggest that Mycoplasma bovigenitalium might be recognized by mononuclear cells as an aggressor faster than other mycoplasmas, what would explain his transitory effect. Our previously studies showed that vaginal samples positive for Mycoplasma bovigenitalium were always obtained from cows or heifers with a severe vaginal lesion score, denoting the acute form of the infection [7,6]. Mycoplasma bovigenitalium is described as a mastitis pathogen, and it has been suggested that the source for mastitis may be from infected vaginal discharge 
running down onto the udder and teats. M. bovigenitalium was rarely diagnosed in clinical samples of cows, but more often in cows with a history of abortions [19].

Some previous studies reported the response of mice macrophages to Ureaplasma diversum, and the results showed values ranging from 0.46 to $0.96 \mathrm{nM} / \mathrm{mL}$. Peripheral blood mononuclear cells, however, did not react when stimulated with a pathogenic strain of Ureaplasma diversum [20,21].

Positive cultures from the three tested bacteria after the $\mathrm{NO}$ assay in similar concentrations to those present in the material used to stimulate NO production may indicate that the cytotoxic effect of NO [22] was not effective on these microorganisms, as long their replication was maintained.

The mycoplasma lipoproteins stimulate the host's immune response, but mycoplasmal infections are not necessarily associated with a severe inflammatory response, and some mycoplasmas colonize the respiratory and urogenital tract without apparent symptoms, suggesting the existence of suppressive mechanisms to the proinflammatory cytokines, which induce the NO synthesis [9,23]. These mechanisms may be connected with a regulatory failure of the immune response, impairing the recognition of the aggressor.

Under normal conditions, parasitism of intracellular microorganisms induce the production of $\mathrm{NO}$ by mononuclear cells, predominantly by macrophages, and the released NO acts on the tissues near the inflammatory focus, leading to cell death, and thus, killing the internal parasites. The fact of mycoplasmas and ureaplasmas have an extracellular mechanism might prejudice the recognition of the aggressor from the host, resulting in smaller amounts of NO released in in vitro assays.

\section{CONCLUSION}

The results showed that Mycoplasma bovis, Mycoplasma bovigenitalium and Ureaplasma diversum are able to activate cells from the bovine endometrium, vagina and peripheral blood to produce NO, suggesting a role of these cells in the immediate response to the mycoplasma or ureaplasma infection.

\section{Acknowledgements}

This project was supported by the National Council for Scientific and Technological Development (CNPq), Brazil, (Process \#448904/2014-4) and a research grant to MLGambarini (Process \#310581/2016-8).

\section{Authors' contributions}

RNGP carried out the cell collection and culture and NO assay and drafted the manuscript. APJK and MLG conceived the presented idea and participated in its design and coordination. MAOV participated in the design of the study and performed the 
statistical analysis. RCT helped in the cell collection and culture. All authors discussed the results, contributed to and approved the final manuscript.

\section{Declaration of conflicting interests}

Authors declared no potential conflicts of interest with respect to the research, authorship, and/or publication of this article.

\section{REFERENCES}

1. Lysnyansky I, Brenner AN, Benjamin A, Bernstein M, Elad, D, Blum, S, Friedgut O, Rotemberg D: Identification of Mycoplasma bovigenitalium and Mycoplasma canadense from outbreaks of granulopapular vulvovaginitis in dairy cattle in Israel. Vet Rec. 2009, 165: 319-322.

2. Cardoso MV, Scarcelli E, Grasso LMPS, Teixeira SR, Genovez ME: Ureaplasma diversum and reproductive disorder in Brazilian cows and heifer; first report. Anim. Reprod. Sci. 2000. 63: 137-143.

3. Maunsell FP, Woolums AR, Francoz D, Rosenbusch RF, Step DL, Wilson DJ, Janzen ED: Mycoplasma bovis infections in cattle. J. Vet. Intern. Med. 2011, 25: 772-783.

4. Fox LK, Kirk JH, Britten A: Mycoplasma mastitis: A review of transmission and control. J. Vet. Med. Series B. 2005,52: 153-160.

5. Maunsell F, Brown MB, Powe J, Ivey J, Woolard M, Love W, Simecka JW: Oral inoculation of young dairy calves with Mycoplasma bovis results in colonization of tonsils, development of otitis media and local immunity. PLoS One. 2012, 7: e44523.

6. Nascimento-Rocha JM, Oliveira Filho BD, Arnhold E, Pôrto RNG, Lima SF, Gambarini ML: Assessment of cow and farm level risk factors associated with Ureaplasma diversum in pasture-based dairy systems - A field study. An. Acad. Brasil. Ciên. 2017, 89: 1779-1783.

7. Pôrto RN G, Oliveira-filho, BD, Ferraz HT, Caixeta LS, Viu MAO, Gambarini ML: Histopatology of the reproductive tract of Nellore pubertal heifers with genital ureaplasmosis. An. Acad. Bras. Ciênc. 2017, 89:,2987-2996.

8. You X, Zeng Y, Wu Y: Interactions between Mycoplasma lipid-associated membrane proteins and the host cells. J. Z.Univ. SCIENCE B 2006, 7: 342-350.

9. Rottem S: Interaction of Mycoplasmas with host cells. Physiol. Rev. 2003, 83: 417-432.

10. Rosseli M, Keller PJ, Debey RK: Role of nitric oxide in the biology, physiology and pathophysiology of reproduction. Hum. Reprod. Update 1998, 4: 3-24.

11. Li DJ, Liu YF, Li YF, Lv Y, Pei XY,Guo DZ: Significance of nitric oxide concentration in plasma and uterine secretes with puerperal endometritis in dairy cows. Vet. Res. Comm. 2010,34: 315-21.

12. Song X, Li D J, Feng GF, Li B, Liu YF: Dynamic analysis of nitric oxide and total oxidant capacity in cow uterine secretion with subclinical endometritis. J. N. Agric. Univ. (English Edition) 2015, 22: 35-39.

13. Lysnyansky I, Ron Y, Yogev,D: Justaposition of an active promoter to vsp genes via sitespecific DNA inversions generates antigenic variation in Mycoplasma bovis. J. Bacteriol. 2001,183: 5698-5708. 
14. WINSTAT. User's manual WINSTAT® for EXCEL. R. Fitch Software, Bad Krozingen, 2006,131p.

15. Bogdan C: Nitric oxide and the immune response. Nature Immunol. 2001, 2: 907-916.

16. Jungi TW, Valentin-Weigand P, Brcic M: Differential induction of NO synthesis by Grampositive and Gram-negative bacteria and their components in bovine monocyte-derived macrophages. Microb. Pathog. 1999, 27: 43-53.

17. Ghanem ME, Higuchi H, Tezuka E, Hideki I, Bhuminand D, Yoshiaki I, Takeshi O: Mycoplasma infection in the uterus of early postpartum dairy cows and its relation to dystocia and endometritis. Theriogenology, 2013,79: 180-185.

18. Macêdo AAM, Oliveira JMB, Silva BP, Borges JM, Soares LBF, Silva GM, Santos SB, Mota RA, Pinheiro-Júnior JW: Occurrence of Mycoplasma bovigenitalium and Ureaplasma diversum in dairy cattle from Pernambuco state, Brazil. Arq. Bras. Med. Vet. Zootec. 2018, 70: 17981806.

19. Petit T, Spergser J, Aurich J, Rosengarten R: Prevalence of Chlamydiaceae and Mollicutes on the genital mucosa and serological findings in dairy cattle. Vet. Microb.2008, 127: 325333.

20. Chelmonska-Soyta A, Miller RB, Ruhnke L, Rosendal S: Activation of murine macrophages and lymphocytes by Ureaplasma diversum. Can.J.Vet. Res. 1994.58: 275-280.

21. Chelmonska-Soyta, A, Katska, L, Kurpisz, M, Stefaniak, T, Zimecki, M : The effect of Ureaplasma diversum activated mononuclear leukocytes on the development and interferon- $t$ production by bovine IVF-derived embryos. J. Reprod. Immunol. 2001,51: 145-158.

22. Marletta MA: Mammalian synthesis of nitrite, nitrate, nitric oxide, and N-nitrosating agents. Chem. Res. Toxicol. 1988,1: 249-257.

23. Cerqueira NF, Yoshida WB: Óxido Nítrico. Revisão. Acta Cir. Bras. 2002. 17, 417-423.

\section{PROCENA IN VITRO AKTIVACIJE PROIZVODNJE AZOT OKSIDA KAO ODGOVOR BOVINIH EPITELNIH ĆELIJA ENDOMETRIJUMA I VAGINE I MONONUKLEARNIH KRVNIH ĆELIJA NA Mycoplasma bovis, Mycoplasma bovigenitalium i Ureaplasma diversum}

Regiani Nascimento Gagno PÔRTO, Ana Paula JUNQUEIRA-KIPNIS, Marco Antonio de Oliveira VIU, Rafaela Cavalcanti TEIXEIRA, Maria Lucia GAMBARINI

Genitalna mikoplazmoza je stanje koje može biti prisutno u reproduktivnom sistemu goveda, a najznačajniji agensi koji je izazivaju su Mycoplasma bovis, Mycoplasma bovigenitalium i Ureaplasma diversum. Neki od aspekata patogeneze nisu još uvek u potpunosti razjašnjeni. Ova studija je kreirana kako bi se procenila njihova sposobnost stimulisanja mononuklearnih ćelija iz endometrijuma, vagine i periferne krvi krava u ciklusu i zdravih krava da proizvode azotni oksid (NO). Ćelijske kulture ćelija endometrijuma, vagine i periferne krvi 33 zdrave krave uzgajane su sa Mycoplasma bovis, Mycoplasma bo- 
vigenitalium i Ureaplasma diversum proisteklim iz 4 pasaže u bujonu, a proizvodnja NO merena je Greiss reakcijom. Potvrda prisustva mononuklearnih ćelija, kao i infektivnih agenasa tokom i posle određivanja NO, urađena je Giemsa bojenjem na razmazima, kao i daljom kultivacijom i detekcijom PCR reakcijom. Mononuklearne ćelije iz svih uzoraka proizvodile su NO. Mycoplasma bovigenitalium stimulisala je veću proizvodnju NO od ostalih $(p<0,05)$. Ćelije endometrijuma proizvode manje NO od ćelija vagine ili krvi. U zaključku se čini da su Mycoplasma bovis, Mycoplasma bovigenitalium i Ureaplasma diversum sposobni da aktiviraju mononuklearne ćelije i indukuju proizvodnju NO, što sugeriše da je ovaj put izazvan kao odgovor na primarnu infekciju ovim agensima. Potrebno je više radova kako bi se verifikovalo zašto ovi agensi dugo ostaju u reproduktivnom traktu goveda i kako ponovo preuzimaju štetne efekte. 